\title{
HYPO-HYPERONYMIC RELATIONSHIP BETWEEN PAREMA AND ITS UNITS
}

\author{
Shodiya Azizovna Ganieva
}

Doctor of Philosophy (PhD) in Philology, Associate Professor, Fergana State University, Uzbekistan

\section{ABSTRACT}

The article discusses with paremas, their features, hypo-hyperonymic relations between parema and its constituent units, integral and differential sign of each unit.

KEYWORDS: - Free compound, fixed compound, marked mark, unmarked member, hyperonym, hyponym, integral sign, differential sign.

\section{INTRODUCTION}

It is known that the differential sign of free and stable compounds is the sign of "readiness" or "stability". According to this sign, a fixed compound member of a word that is in opposition is a strong, marked, and a free member is a weak, unmarked member. All stable compounds, therefore, form a whole with the sign of "readiness". The sign of "readiness" means that these compounds are pre-assembled, rounded, ready in the language before the speaker's speech. The "stability" sign indicates the continuity of its components.

Although stable compounds have a commonality in terms of "readiness" and "stability", they differ in certain differential characteristics. So, it is divided into small groups on the basis of these characters. It seems that the signs of "stability" serve as a unifying, integral sign of stable compounds.

Stable compounds have been called differently by different authors to this day. In particular, in the "Linguistic Encyclopedic Dictionary", all such combinations are expressed under the term "phraseology", idioms, proverbs and sayings; winged words, aphorisms; How are things? Are you in a good mood? such stamps are included in its composition. Signs of "semantic transposition", "stability" and "readiness" are recognized as important and universal features of phraseology [1,559].

\section{T HE MAIN FINDINGS AND RESULTS}

In the interpretation of phraseologies, the term parema is also recommended for all stable compounds. At this time, the parema contains all the stable compounds. Phraseologism is 
CURRENT RESEARCH JOURNAL OF PHILOLOGICAL SCIENCES 2(6): 84-87,

May 2021 DOI: https://doi.org/10.37547/philological-crjps-02-06-17

ISSN 2767-3758

(C)2021 Master Journals

\section{Crossref do) 8 Google}

Accepted25thJune, 2021 \& Published 30thJune, 2021

interpreted as a type of parema. In particular, $\mathrm{H}$. Berdiyorov and R. Rasulov differentiate between paremiology, which studies parems, and phraseology, which studies phraseology. It is argued that paremiology is inextricably linked with phraseology, "that if paremiology studies all phraseologies of different character in language, phraseology as a part of it studies only fixed combinations of portable meanings" $[2,10]$.

In this case, there is a hypo-hyperonymic relationship between parema and phraseology, with parema being hyperonym and phraseology being hyponym. In addition to the sign of "hypohyperonymy", the sign of "semantic transposition" serves as a distinguishing mark between these two units. According to the sign of "semantic transpositivity", parema and phraseology enter into a mutually privative opposition. The parema that forms the left member in a pair of opposing members is weak, unmarked, and the phraseologisms that make up the right member are considered strong, marked markers.

Stable compounds as a whole are not initially limited to division into parema and phraseologisms, both species themselves have the property of internal division. In particular, it contains several types of stable compounds. In particular, the authors of paremiological dictionaries add proverbs, parables, aphorisms to the list of paremiological units $[2,11]$.

Hence, these authors recognize proverbs, parables, and aphorisms as separate units united into a class, a paradigm, on the basis of a certain integral sign, and at the same time, distinguished on the basis of certain differential signs.

Some authors, on the other hand, deny that proverbs, parables, and aphorisms are separate units, emphasizing that they are different names for the same phenomenon. For example, in the foreword to the book "Uzbek folk proverbs" by academician Sh. Shoabdurahmanov we read the following: "Although proverbs are found in many forms, such as proverbs, parables, wisdom, wise sayings, proverbs, parables, they are strengthened in the form of proverbs in modern Uzbek" [3,5].

From the above, it is clear that the author understands proverbs, parables and aphorisms as a single phenomenon and does not pay attention to their specific features.

G.Salomov distinguishes proverbs and parables: "A proverb is a phraseologism and speech that is widely used in language, figuratively expressing things and events. The proverb expresses the speaker's attitude to the content of his speech "[4,258]. The author considers the idiom to be a stable phrase with an indivisible, portable meaning [4,263]. The scientist distinguishes proverbs, sayings, idioms and includes them all in phraseology $[5,118]$.

Currently, many authors recognize the distinctive features of each of them and emphasize that they are separate units $[5 ; 6]$.

Proverbs, parables, and wise sayings, i.e., aphorisms, are recognized as components of parems. Their unifying features are "stability", "readiness", "semantic transposition". If these three characters are important signs of parems, and these signs are paradigm-forming characters, then it is necessary to add riddles to the paradigm of paremas. Because the riddles also embody the above three characters that make up the paradigm of paremas. For example, the stability of the components of a compound, such as one without a snow, one eye with a thousand, which does not stand on a pile, forms a commonality with stable compounds according to the signs that it is ready to be introduced into the speech by the speaker. If we add riddles to the list of stable compounds according to these integral signs, then the structure of paremas consists of proverbs, parables, wise sayings and riddles. 
CURRENT RESEARCH JOURNAL OF PHILOLOGICAL SCIENCES 2(6): 84-87,

May 2021 DOI: https://doi.org/10.37547/philological-crjps-02-06-17

ISSN 2767-3758

(C)2021 Master Journals

\section{Crossref do) 8 Google}

Accepted25thJune, 2021 \& Published 30thJune, 2021

In particular, the paremiological unit closest to the proverbs is the proverb. Proverbs and parables are so close to each other that although in many literatures the names of proverbs and parables are mentioned separately, but in most cases they do not differ from each other. In some literatures, however, different characters are considered as distinguishing marks. In particular, H.Berdiyorov and R.Rasulov wrote the article "Grammatically complete idea, small, concise, sharp, portable or wise folk expressions used both in the figurative sense and in their own sense", and in the article "Educational, instructive", grammatically complete sentences, but in their own sense - short, concise phrases that are used in the correct sense.

It can be seen that in these definitions the distinctive sign between the above two units is taken as the sign of "portable usage", "semantic transpositivity". At the same time, it is stated that the proverbs are neutral in relation to this sign, some are used in a figurative sense, and some are not used in a figurative sense. Thus it is recognized that a group of proverbs merges with a parables, the disappearance of the distinguishing sign between them, as a result of which a single stable unit in its meaning becomes indistinguishable when a proverb can be considered a proverb. Therefore, in the "Explanatory Dictionary of the Uzbek language" as a differential sign between a proverb and a parables is taken not the sign of "semantic transposition", but the sign of "informative completeness", and this sign serves to clearly distinguish members of the opposition.

The two-volume "Encyclopedic Dictionary" also gives a similar definition to the article $[8,498]$. At this time, proverbs have the sign of "informative completeness", which is characterized by a strong member of the contradiction, and the proverb does not have such a sign. This member is considered weaker than the character on which the opposition is based.
In the paradigm of stable "paremas", proverbs and aphorisms are also close to each other. In the "Explanatory Dictionary of the Uzbek language" aphorisms are described as "profound, short, concise, wise words" $[9,63]$, while H.Berdiyorov and R.Rasulov emphasize that "aphorisms are expressive, concise words of wisdom". There are two types: they state that there are verbal and linguistic aphorisms, and that aphorisms about a particular person are spoken, popularized, and become public property are linguistic aphorisms $[2,12]$.

In terms of the stability of the lexical units in the composition, it is also possible to include riddles in the series of paremas. Because they also have the characteristics of "stability" and "readiness" typical of parems. In the "Explanatory Dictionary of the Uzbek Language", riddles are "descriptions of things, events, etc., expressed through symbols and analogies; puzzle" $[9,148]$. So, the significant features of the puzzles are "stability", "readiness" and "puzzle". The last character serves to distinguish puzzles from other stable compounds.

\section{Conclusion}

Thus, the units of stable compounds are distinguished by the signs of "stability", "readiness", "semantic transpositivity", "informative completeness" [10,38]. If they are considered a stable compound with a common sign, each is distinguished by a differential sign.

\section{ReFERENCES}

1. Linguistic Encyclopedic Dictionary, Moscow: 1990.

2. Berdiyorov X., Rasulov R. Paremiological dictionary of the Uzbek language. Tashkent: 1982.

3. Shoabdurahmonov Sh. Folk wisdom // Uzbek 
CURRENT RESEARCH JOURNAL OF PHILOLOGICAL SCIENCES 2(6): 84-87,

May 2021 DOI: https://doi.org/10.37547/philological-crjps-02-06-17

ISSN 2767-3758

(C)2021 Master Journals

Crossref do) 801 Google

Accepted25thJune, 2021 \& Published 30thJune, 2021

folk proverbs. Tashkent: Fan, 1984.

4. Salomov G. Language and translation.

Tashkent: Fan, 1966.

5. Salomov G. Fundamentals of translation theory. Tashkent: Teacher, 1983.

6. Joraeva B.M. Doctor of Philological Sciences ... diss. avtoref. Samarkand: 2019.

7. Joraeva B.M. Linguistic position and spiritualmethodical application of proverbs: Philol. candidate of sciences ... diss. avtoref. Tashkent: 2002.

8. Encyclopedic Dictionary. 2 volumes. Volume 1 Tashkent: 1988.

9. Annotated dictionary of the Uzbek language. 5 volumes. The fourth volume. Tashkent: Uzbekistan Publishing House, 2020.

10. Ganieva Sh. Structural study of Uzbek phraseology. Tashkent: Fan, 2013.

11. Karimov, U., \& Abdurakhmon, A. (2017). INNOVATIVE INFORMATION TECHNOLOGY IN EDUCATION. Форум молодых ученых, (5), 9-12.

12. Oripova, G. (2019). Uzbek poetry and the world literature in the years of independence. Scientific Journal of Polonia University, 32(1), 116-120. 